\title{
Tectonic control on slow-moving Andean landslides in the Colca Valley, Peru
}

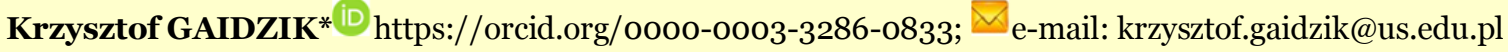 \\ Jerzy ŻABA iDttps://orcid.org/oooo-ooo2-4717-1793; e-mail: jerzy.zaba@us.edu.pl \\ Justyna CIESIELCZUK ${ }^{\circledR}$ https://orcid.org/oooo-0001-6681-825X; e-mail: justyna.ciesielczuk@us.edu.pl \\ ${ }^{*}$ Corresponding author \\ Institute of Earth Sciences, University of Silesia, Będzińska 6o, 41-20o Sosnowiec, Poland
}

Citation: Gaidzik K, Żaba J, Ciesielczuk J (2020) Tectonic control on slow-moving Andean landslides in the Colca Valley, Peru. Journal of Mountain Science 17(8). https://doi.org/10.1007/s11629-020-6099-y

(C) The Author(s) 2020.

\begin{abstract}
The Colca Valley in the Central Andes is a region characterized by the occurrence of large slowmoving landslides and a high level of seismic activity. In this study, we aimed to determine passive and active tectonic control on the formation of selected five large landslides in the Colca Valley and to assess geohazard associated with these features. For that purpose, we performed a post-landslide field survey, applied remote sensing techniques, and obtained eyewitness accounts. Recently, the need to understand mass movement processes in this region is even higher due to the establishment of the Colca y Volcanes de Andagua Geopark (Colca and Andagua Volcanoes Geopark). Our results suggest that the studied landslides usually represent a complex failure mechanism, dominated by translational sliding or rotational displacements, commonly associated with the formation of horst-and-graben like structures. We found a spatial correlation between the distribution of landslides and inherited fault network. The head scarps appear to be limited by the WNW- to NWstriking faults, whereas the lateral extent of some of the reported features seems to be connected with the NNE-striking normal faults, common in both, the Mesozoic strata and the Pleistocene-Holocene deposits.
\end{abstract}

Keywords: Landslide; Geohazard; Tectonic activity; Earthquake; Central Andes; Peru

Received: 26-Mar-2020

Revised: 11-Jun-2020

Accepted: 13-Jul-2O2O

\section{Introduction}

Landslides are one of the most dangerous geohazards, resulting in human death, economic loss, and environmental impact. Each year ca. 400 fatal landslides worldwide result in more than 4,500 fatalities (Petley 2012). Landslides encompass a wide variety of types and sizes, usually divided into five main groups of movement: falls, topples, slides, spreads, and flows (Hungr et al. 2014). Major natural triggering mechanisms include water, seismic activity, and volcanic activity. Their effects vary widely and depend on internal factors such as lithology, tectonic structures, soil type, vegetation, and the occurrence of earlier landslides, as well as topographic characteristics such as morphology, slope steepness, slope aspect, slope profile, solar radiation, etc. (e.g. Guzzetti et al. 2008; Wu and Qiao 2009; Lacroix et al. 2013, 2014, 2015, 2019; Zerathe et al. 2016; Gaidzik et al. 2017; Ramírez-Herrera and Gaidzik 2017; Samia et al. 2017). Tectonic processes produce lines of weakness and failure surfaces (passive role) affecting the slopes, as well as the topographic growth and over-steepening of the slopes (active role) that promote the occurrence of large landslides (Carlini et al. 2016).

Slope saturation with water and shaking 
caused by earthquakes are the primary causes of mass movements (e.g. Malamud et al. 2004; Tanyaş et al. 2017). Saturation is usually a result of an extreme rainfall event, such as a hurricane or storm in tropical climates, triggering thousands of landslides, from shallow soil slips and debris flows to catastrophic large deep-seated landslides (e.g. Larsen and Torres-Sanchez 1992; Buckham et al. 2001; Cannon et al. 2001; Harp et al. 2002; Ramírez-Herrera and Gaidzik 2017). Worldwide examples also prove that large earthquakes are indeed major triggers for numerous landslides (Malamud et al. 2004; Tanyaş et al. 2017), e.g., the 7.4 Khait earthquake (1949) in Tajikistan (Evans et al. 2009), the 6.6 Chuetsu earthquake (2004) in Japan (Wang et al. 2007), the 8.o Pisco earthquake (2007) in Peru (Lacroix et al. 2013), the 7.9 Wenchuan earthquake (2008) in China (Gorum et al. 2011), and the 7.8 Gorkha earthquake (2015) in Nepal (Kargel et al. 2015). All of these seismic events produced thousands of mass movements of rock and soil on otherwise metastable slopes, sometimes occurring rapidly with very little warning, exacerbating the danger to human settlements in areas of seismic and/or volcanic activity. However, seismicity does not trigger landslides only immediately following an earthquake. Multiple earthquakes can also have long-term effects on slope integrity, thus acting as preparatory and causal factors contributing to landslides, decreasing slope stability through seismically-induced damage (e.g. Wolter et al. 2016; Bontemps et al. 2020). Moreover, slow-moving landslides can be dynamically triggered/ reactivated/accelerated by the shaking of the seismic waves during earthquakes (coseismic displacement) followed by a relaxation period during which slip rate decays to reach its long-term rate (postseismic displacement) (Newmark 1965; Moro et al. 2011; Lacroix et al. 2014, 2015).

Seismically driven landslides are particularly common in regions of active subduction zones (Tanyaş et al. 2017). A situation of this kind can be observed in the Colca Valley in the Central Andes, southern Peru, located $\sim 270 \mathrm{~km}$ from the trench where the Nazca Plate is subducted beneath the South American Plate, resulting in a high level of seismic activity in this area (e.g. Chlieh et al. 2011) (Figure 1a). Inventory of landslides after the Arequipa earthquake in 2001 (M 8.3) (Tavera et al.
2002) proved that large subduction earthquakes can produce mass movement features in this region that might affect local communities (Gomez et al. 2002). Seismic events of magnitudes greater than 4.0, the smallest earthquake magnitude known to produce landslides (Keefer 1984), are frequent here and associated with shallow crustal faults. The Colca Valley's location between two active volcanoes, Sabancaya and Mismi (Figure 1a), amplifies the landslide hazard, as their activities can trigger giant landslides or debris flows (e.g. Marui and Nadim 2009). Moreover, volcanic eruptions produce loose ash deposits (easy to mobilize), and heavy rain that could saturate the ground leading to mass movement processes. Seismic shocks and seasonal rainfall cause significant mass movements, especially on steep valley slopes covered with Pleistocene-Holocene lacustrine and colluvium deposits (Guillande and Salas 1995; Bulmer et al. 1999; Antayhua et al. 2002; Gomez et al. 2002; Ocola and Gómez 2005; Żaba and Małolepszy 2008; Zavala et al. 2013; Lacroix et al. 2014, 2015; Zerathe et al. 2016; Bontemps et al. 2018, 2020). The Colca Valley is classified as a zone of a very high geohazard risk (at a level of 9 on a scale of 10) (Ocola and Gómez 2005), proving landslide activity in this area. The landslide geohazard assessment in this area is of crucial importance for the recently-established Colca y Volcanes de Andagua Geopark. Thus, the main motivation for this research is the understanding of mass movement processes in the area of very high geohazard that presents an actual threat for local communities, and the recognition of the relationship between tectonic processes and landslides.

This study focuses on the physical characteristics of selected five large slow-moving landslides in the Colca Valley between Chivay and Pinchollo (Figure 1b). We aimed to determine passive and active tectonic control on landslide formation and to assess environmental risks associated primarily with earthquakes which result in ground disturbances and deformations, landslide processes, and flows of mud, debris, and muddebris. For that purpose, we 1) performed a postlandslide field survey including geomorphological observations and measurements of landsliderelated features and structural studies in selected outcrops and the collection of eyewitness accounts, and 2) applied remote sensing techniques using 

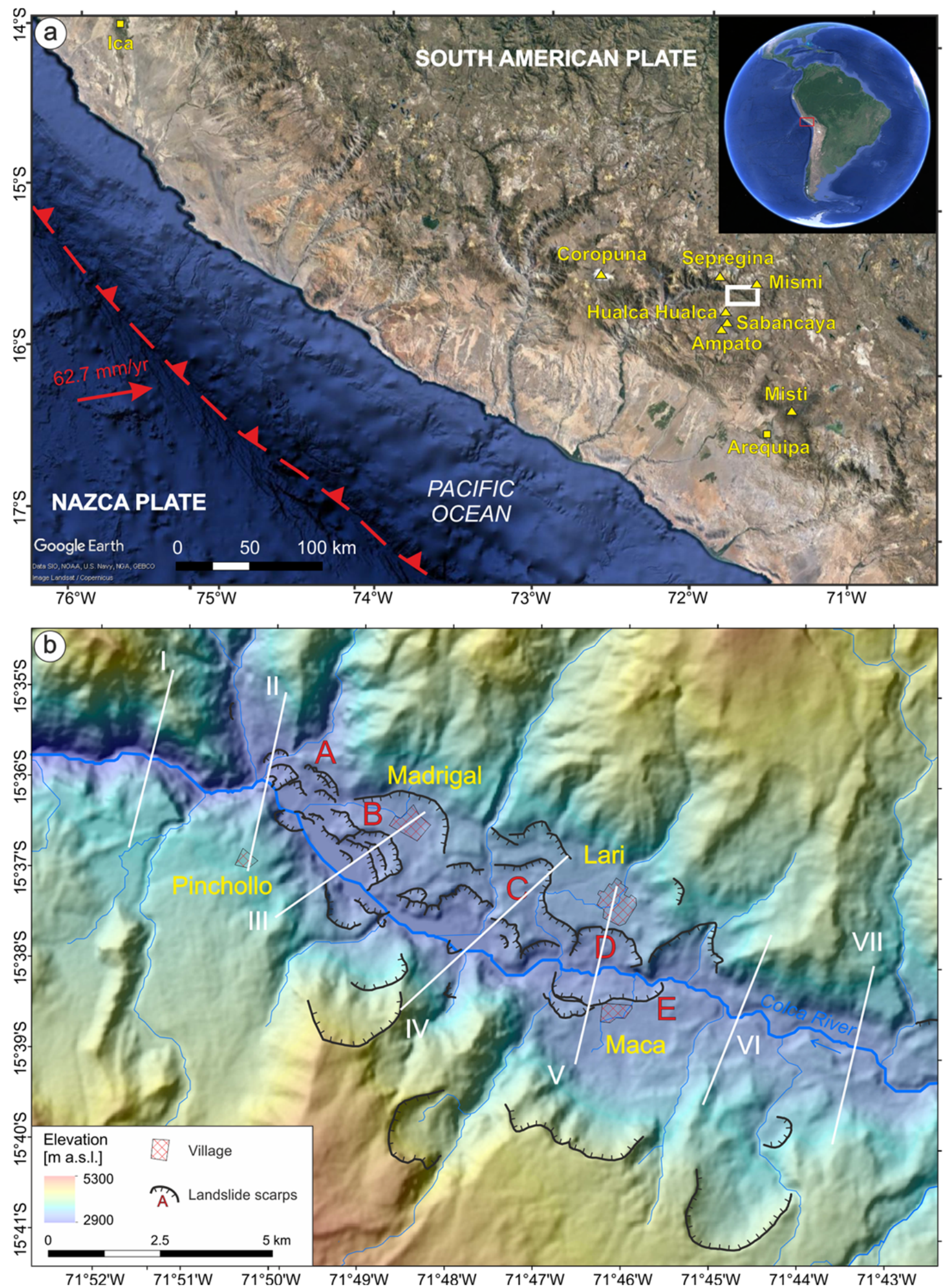

Figure 1 (a) Tectonic setting of the study area; white rectangle shows the location of Figure $1 \mathrm{~b}$; yellow triangles indicate major volcanoes, and yellow squares show main cities; arrowheads show subduction zone, the red arrow indicates the direction of convergence and convergence rate in $\mathrm{mm} / \mathrm{yr}$ (Chlieh et al. 2011); (b) Topography of the study area (30 m resolution digital elevation model, DEM from Shuttle Radar Topography Mission, SRTM (Farr and Kobrick 2000; https://earthexplorer.usgs.gov/) with the location of studied landslides (A-E); I-VII - transverse profiles presented in Figure 2a. 
satellite images and a 30-meter resolution digital elevation model (DEM) from the Shuttle Radar Topography Mission (SRTM) (Farr and Kobrick 2000). We discussed the possible failure mechanisms, triggering factors, the role of inherited tectonics structures, and the potential impact of seismic activity on the landslide development.

\section{Study Area}

The Colca Valley is located in the western Cordillera (central volcanic zone of the Andes) in southern Peru (Figure 1a). The studied section of the Colca Valley experiences a high level of seismic and volcanic activity. Seismic activity is mainly related to the subduction of the Nazca Plate beneath the South American Plate at the convergence rate of 6-7 cm/yr (Figure 1a), which can generate large earthquakes of magnitudes greater than 8 (Chlieh et al. 2011). However, apart from the interplate megathrusts and intermediatedepth intraslab earthquakes, there are also numerous active regional shallow crustal faults around the area (Żaba et al. 2012; Benavente et al. 2017) that can also produce seismic events catastrophic for the local communities, triggering mass movement processes (e.g. Antayhua et al. 2002; Tavera et al. 2016). The Colca Valley is situated between two major Neogene volcanic massifs represented primarily by stratovolcanoes: Sepregina (5,597 $\mathrm{m}$ a.s.l.) and Mismi (5,597 $\mathrm{m}$ a.s.l.) to the north and Hualca Hualca $(6,025 \mathrm{~m}$ a.s.l.), Sabancaya (5,976 m a.s.l.), and Ampato (6,288 m a.s.l.) to the south (Figure 1a). Frequent seismic events of magnitudes $<3$ related to the volcanic activity can have long-term effects on slope integrity, i.e. decreasing the slope stability (Wolter et al. 2016).

We studied the WNW- and W-trending middle section of the Colca Valley, c. $20 \mathrm{~km}$ along the Colca River, between the villages of Chivay and Pinchollo, just before the Colca Canyon (Figures 1b, 2a and 2b). The valley bottom on the studied section drops from $3,280 \mathrm{~m}$ a.s.l. in the east to approximately $3,140 \mathrm{~m}$ a.s.l. in the western part, below the Pinchollo village, resulting in a gradient of $7.8 \mathrm{~m} / \mathrm{km}$ for the Colca Valley (Figure 2a). The downstream section, regarded as the Colca Canyon, shows a much steeper gradient reaching almost $40 \mathrm{~m} / \mathrm{km}$ (Figure 2a). Also, the general morphology of the valley and valley slopes vary significantly between the Colca Valley and Canyon; i.e. much higher and steeper slopes in the Colca Canyon (Figures 2a and 2b).

Early Cretaceous dark grey quartzite, quartz sandstone, and shale occur locally in the bedrock of the studied section of the Colca Valley (Figure 3a). Bedding planes in the Mesozoic sedimentary strata strike W-E, with a gentle dip $\left(0^{\circ}-35^{\circ}\right)$ towards the south and north (Żaba et al. 2012). These formations are folded slightly, forming W-trending folds that gently plunge towards the east. A complex fault network cross-cuts and displaces the bedrock: strike-slip faults (both dextral and sinistral), normal dip-slip faults, and much rarer reverse faults can be observed (Figure 3a and 3b) (Żaba et al. 2012). Some of these local normal (extensional) W-striking faults are associated with the top of anticlines. Most of these faults, however, show signs of multiphase activity related to transformations from reverse or strike-slip to the normal mechanism.

Consequently, white tuffs of the Tacaza group and andesitic lavas from the Mismi volcano were deposited during the Oligocene-Miocene on deformed Mesozoic sedimentary strata (Figure 3a). More recently horizontally stratified lacustrine sediments were sparsely distributed on the slopes and bottom of the Colca Valley (Torres and Muñoz 2009). These are represented by white, silty, or locally sandy tuffites, formed in the lake-filled tectonic intermontane grabens related to the uplift of the Andes in the Late Pliocene/Early Pleistocene (Sébrier et al. 1988; Hsü 1992; Thouret et al. 2007; Kukulak et al. 2016). Tectonic disturbances of these sediments, indicated by a steep inclination of the laminated strata, together with minor synsedimentary, and younger faults, suggest the tectonic activity during the existence of the lake and after its draining (Kukulak et al. 2016). The lake was created by the damming of the Colca River in the area of Pinchollo by a massive rock-avalanche triggered on the volcanic slopes of Hualca Hualca in the Late Pleistocene (Figure 3a) (Thouret et al. 2007; Gómez et al. 2004). The landslide dam-lake was about $20 \mathrm{~km}$ long, $3 \mathrm{~km}$ wide, and $200 \mathrm{~m}$ deep. Similar giant paleolandslides produced by large gravitational slope failures are frequent features in the central part of the Western Andes (e.g. Delgado et al. 2019). 
(a)
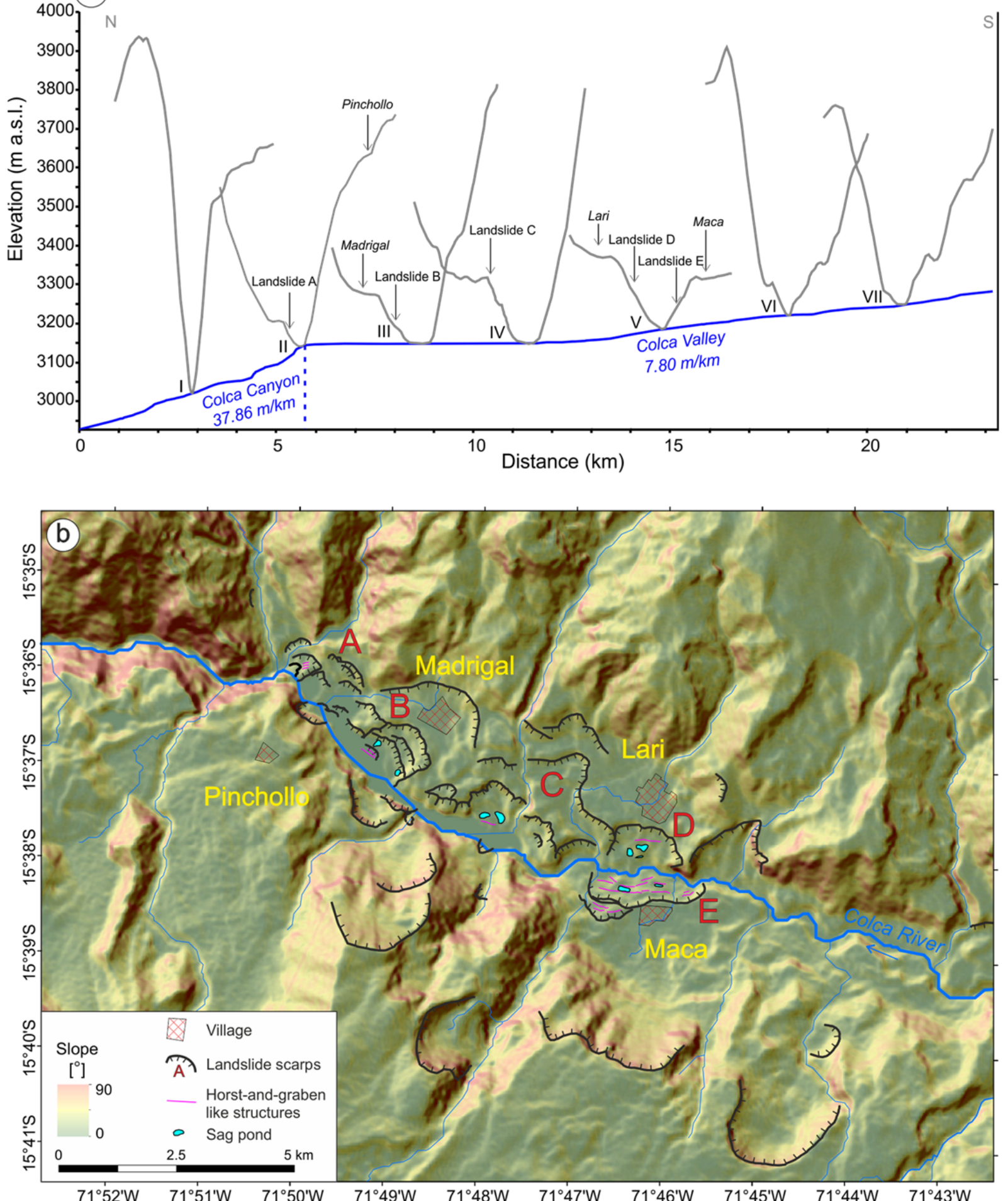

Figure 2 (a) Colca River longitudinal profile along the studied section (shown in Figure 1b) showing river gradient in both, Colca Valley and Colca Canyon, together with 7 transverse profiles I-VII (for locations see Figure 1b), presenting the location of studied landslides and closest villages. Profiles were computed based on a 30 m resolution SRTM digital elevation model (Farr and Kobrick 2000; https://earthexplorer.usgs.gov/). (b) Slope map of the study area with the location of studied landslides. Horst-and-graben like structures and sag ponds are indicated. A-E - studied landslides (for details see text). Note that studied landslides were developed on relatively gentle slopes inside the Colca Valley. 


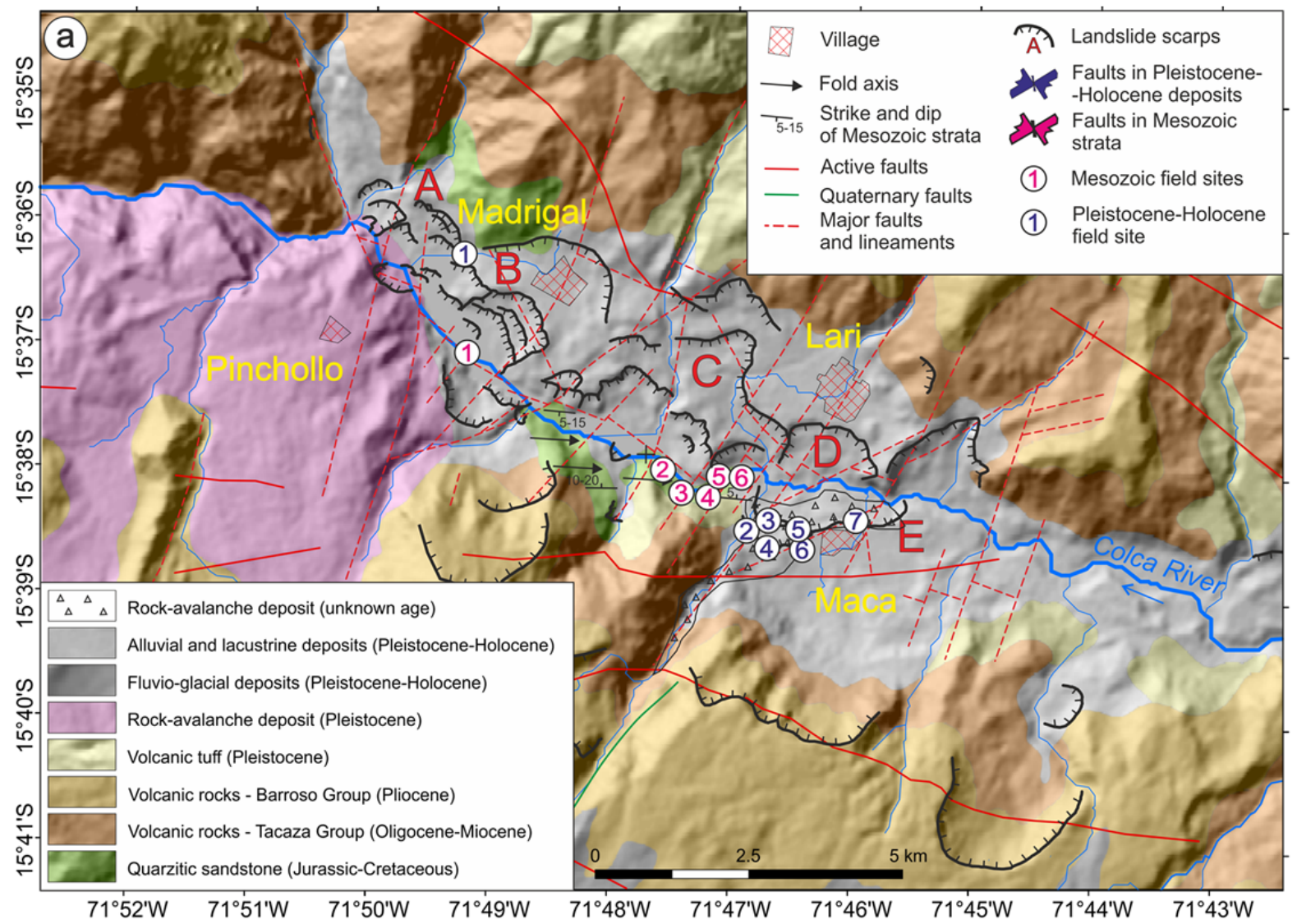

(b)
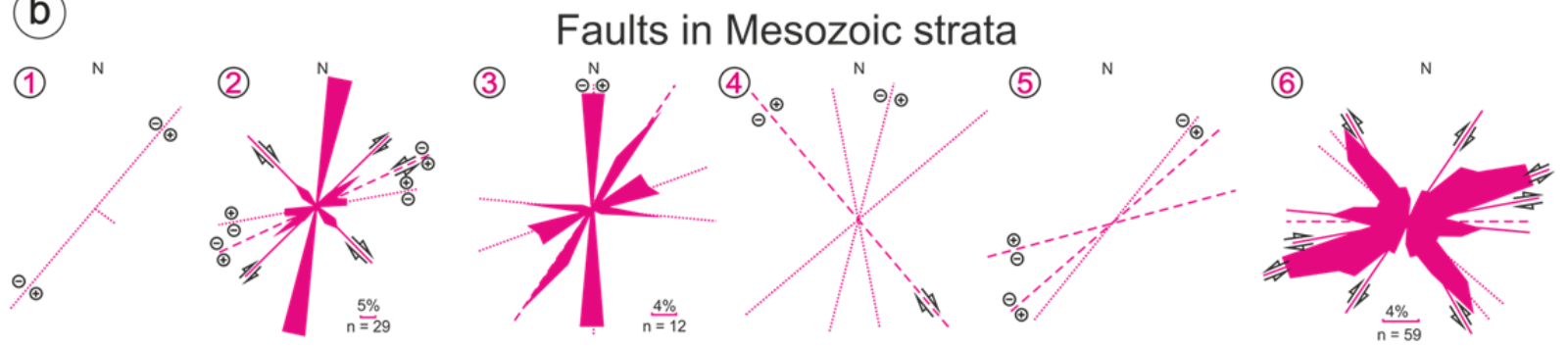

Faults in Pleistocene-Holocene deposits

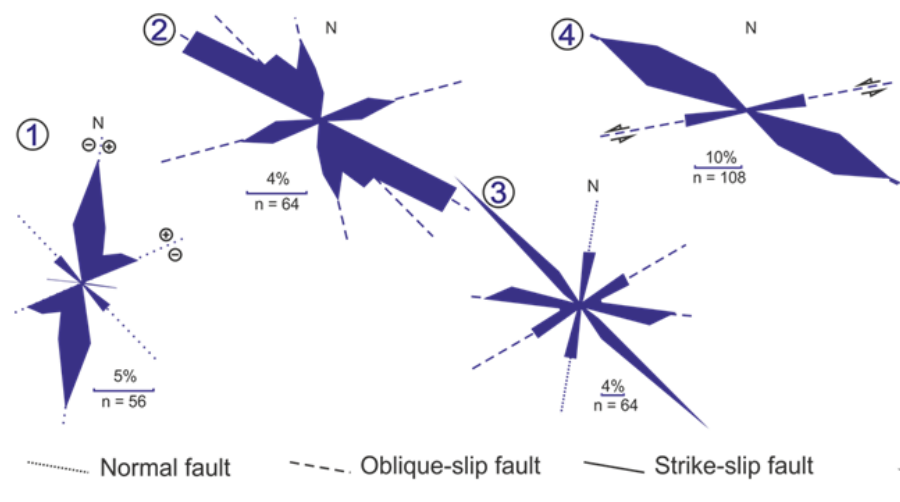

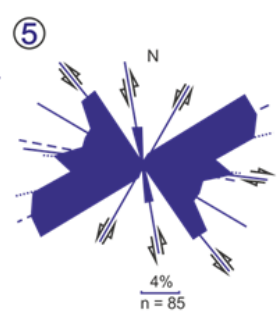

Direction and sense of $\Rightarrow$ relative horizontal

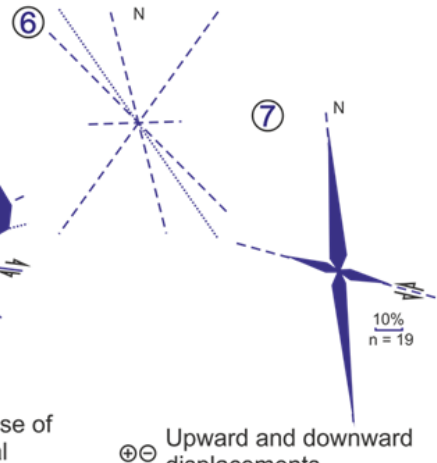

$\oplus \odot$ Upward and downward

Figure 3 (a) Geology of the study area (after Torres and Muñoz 2009, and Zerathe et al. 2016; modified), and fault network: major faults and lineaments (after Żaba et al. 2012), active and Quaternary faults (after Benavente 2017), A-E - studied landslides (for details see text); (b) Spatial orientation and kinematics of faults recorded in both, Mesozoic strata and Pleistocene-Holocene deposits. 
We identified several landslides in the studied section of the Colca Valley (Figures 1b, 2b, and 3a). In this study we will focus on the most prominent and largest forms represented by five landslides: A) beneath Pinchollo; B) in Madrigal; C) between Madrigal and Lari; D) in Lari; and E) in Maca (Figures 1b, 2b, and 3a; Table 1) (see also Ocola and Gómez 2005; Żaba and Małolepszy 2008; Zavala et al. 2013; Lacroix et al. 2014, 2015; Zerathe et al. 2016; Bontemps et al. 2018, 2020). Four of these landslides occur on the right (northern) slopes of the asymmetric Colca Valley (Figures 1b, 2a, and 2b). The last (E) developed on the left bank of the river in the vicinity of Maca is widely described in the literature (e.g. Żaba and Małolepszy 2008; Zavala et al. 2013; Lacroix et al. 2014, 2015; Zerathe et al. 2016; Palmer 2017; Bontemps et al. 2018, 2020).

Landslides in this area were developed primarily in the Cenozoic sediments, dominated by the Holocene colluvial and alluvial deposits, whose thickness commonly exceeds $100 \mathrm{~m}$. Most of the landslides involve the Pleistocene lacustrine sediments interbedded by tuffite layers recognized at different levels of the Colca Valley. Furthermore, some shallow landslides were also developed within the Quaternary regolith covers and locally within the Upper Pleistocene deposits (Torres and Muñoz 2009) formed by mud and debris flows. Landslide in Maca involves also the rock-avalanche deposit of unknown age (Figure 3a) (Zerathe et al. 2016).

\section{Materials and Methods}

We performed a post-landslide field survey and applied remote sensing techniques using satellite images and a $30 \mathrm{~m}$ resolution digital elevation model (DEM) from the Shuttle Radar Topography Mission (SRTM) obtained from USGS (Farr and Kobrick 2000; https://earthexplorer. usgs.gov/). The post-landslide field survey included 1) geomorphological observations and measurements of landslide-related features (spatial orientation and dimensions), i.e. main and secondary scarps, horst-and-graben like structures, fissures, sag ponds, etc., along with landslide mapping, and 2) structural studies within the selected Mesozoic (6 sites) and PleistoceneHolocene (7 sites) outcrops on slopes and at the bottom of the Colca Valley. We attempted to differentiate in the field sections of landslide with evidence of recent activity (e.g., extensional features, saturation with water, sag ponds, lack of vegetation, etc.) and those that are relatively more stable (e.g., high vegetation, human settlements, agriculture, etc.). For measurements of landform features, we used measuring tape and a laser rangefinder. In the bedrock outcrops, we identified and measured mesofaults, fractures, and joints, along with accompanying minor secondary structures. In particular, we were looking for fault mirror surfaces with striations and any evidence of displacements to deduce on the kinematics of recorded structures. Using superposition analysis, we also determined their relative age relationships. Obtained results are presented in the form of rose diagrams showing variation in faults strike, together with the principal fault type of a defined orientation. To make the analysis more complete we used also some published structural data (Żaba et al. 2012). Faults were mapped based on the field measurements and analysis of satellite images, and DEM. During fieldwork, we also gathered eyewitness accounts from residents of Pinchollo, Madrigal, and Lari to corroborate the recent activity of selected landslides (for locations of these villages see Figures $1 b, 2 b$, and $3 a$ ).

The final map of landslides produced in this study is a combination of mapping done in the field and manual inventorying using a visual interpretation of Google Earth satellite images. We used these also to corroborate information on the relative activity of different landslide sections. Topographic profiles, river longitudinal profiles, and transverse profiles were computed using a $30 \mathrm{~m}$ resolution SRTM DEM, verified in several points by our field GPS data (see Figure 2a). We used field GPS measurement and satellite images for the calculation of the main landslide parameters presented in Table 1. Seismic data on major earthquakes of magnitude $M>4.0$ in the area of the Colca Valley for the time period 1976-2017 was derived from the USGS catalog (https://earthquake. usgs.gov/earthquakes/search).

\section{Results}

\subsection{Landslides}

All studied landslides are developed on the 
Table 1 Main parameters of the studied landslides (see Figures 1b, 2b, and 3a).

\begin{tabular}{|c|c|c|c|c|c|}
\hline Landslide & $\begin{array}{l}\text { Beneath Pinchollo } \\
\text { (A) }\end{array}$ & $\begin{array}{l}\text { In Madrigal } \\
\text { (B) }\end{array}$ & $\begin{array}{l}\text { Between Madrigal } \\
\text { and Lari (C) }\end{array}$ & $\begin{array}{l}\text { In Lari } \\
\text { (D) }\end{array}$ & $\begin{array}{l}\text { In Maca } \\
\text { (E) }\end{array}$ \\
\hline Location & $\begin{array}{l}\text { right (northern) bank } \\
\text { of the Colca River }\end{array}$ & $\begin{array}{l}\text { right (northern) bank } \\
\text { of the Colca River }\end{array}$ & $\begin{array}{l}\text { right (northern) bank } \\
\text { of the Colca River }\end{array}$ & $\begin{array}{l}\text { right (northern) bank } \\
\text { of the Colca River }\end{array}$ & $\begin{array}{l}\text { left (southern) bank } \\
\text { of the Colca River }\end{array}$ \\
\hline $\begin{array}{l}\text { Min. elevation } \\
\text { (m a.s.l.)* }\end{array}$ & $3070 \pm 10$ & $3038 \pm 8$ & $3098 \pm 7$ & $3162 \pm 7$ & $3154 \pm 4$ \\
\hline $\begin{array}{l}\text { Max. elevation } \\
\text { (m a.s.l.)* }\end{array}$ & $3276 \pm 14$ & $3272 \pm 10$ & $3420 \pm 15$ & $3425 \pm 12$ & $3305 \pm 10$ \\
\hline Height $(\mathrm{m})^{*}$ & $206 \pm 24$ & $234 \pm 18$ & $322 \pm 22$ & $263 \pm 19$ & $151 \pm 14$ \\
\hline Length $(\mathrm{km})^{\#}$ & $0.9 \pm 0.1$ & $1.8 \pm 0.1$ & $2.4 \pm 0.3$ & $0.9 \pm 0.1$ & $1.0 \pm 0.1$ \\
\hline Width $(\mathrm{km})^{\#}$ & $0.8 \pm 0.1$ & $1.6 \pm 0.1$ & $3.2 \pm 0.1$ & $1.8 \pm 0.1$ & $1.8 \pm 0.1$ \\
\hline Area $\left(\mathrm{km}^{2}\right)^{\#}$ & $0.7 \pm 0.1$ & $1.5 \pm 0.1$ & $5.2 \pm 0.2$ & $1.2 \pm 0.1$ & $1.3 \pm 0.1$ \\
\hline $\begin{array}{l}\text { Landslide } \\
\text { main scarp }\end{array}$ & $\begin{array}{l}\text { semicircular outline } \\
\text { (northern scarp - } \\
\text { well marked) }\end{array}$ & $\begin{array}{l}\text { well-marked of } \\
\text { semicircular outline }\end{array}$ & $\begin{array}{l}\text { well-marked } \\
\text { irregular out }\end{array}$ & $\begin{array}{l}\text { well-marl } \\
\text { semicircu }\end{array}$ & $\begin{array}{l}\text { poorly mark } \\
\text { semicircular }\end{array}$ \\
\hline $\begin{array}{l}\text { Landslide } \\
\text { material }\end{array}$ & $\begin{array}{l}\text { mainly colluvial } \\
\text { deposits, also alluvial } \\
\text { and locally lacustrine } \\
\text { sediments }\end{array}$ & $\begin{array}{l}\text { mainly lacustrine } \\
\text { sediments, also } \\
\text { colluvial deposits }\end{array}$ & $\begin{array}{l}\text { mainly lacustrine } \\
\text { sediments, also } \\
\text { alluvial and colluvial } \\
\text { deposits }\end{array}$ & $\begin{array}{l}\text { mainly lacustrine } \\
\text { sediments, also } \\
\text { alluvial and colluvial } \\
\text { deposits }\end{array}$ & $\begin{array}{l}\text { mainly colluvial } \\
\text { deposits, also } \\
\text { alluvial and } \\
\text { lacustrine sediments }\end{array}$ \\
\hline $\begin{array}{l}\text { Relative } \\
\text { activity }\end{array}$ & $\begin{array}{l}\text { lower parts show } \\
\text { evidence of recent } \\
\text { activity }\end{array}$ & $\begin{array}{l}\text { lower parts show } \\
\text { evidence of activity }\end{array}$ & $\begin{array}{l}\text { only in the } \\
\text { lowermost part some } \\
\text { evidence of activity }\end{array}$ & $\begin{array}{l}\text { low activity or } \\
\text { inactive }\end{array}$ & $\begin{array}{l}\text { lower parts show } \\
\text { evidence of activity }\end{array}$ \\
\hline
\end{tabular}

Note: *error refers to the field GPS measurement uncertainty. \#average estimates with standard deviation.

slopes of the Colca Valley at the elevations ranging from $3038 \pm 8 \mathrm{~m}$ a.s.l. to $3425 \pm 12 \mathrm{~m}$ a.s.l. (Figure $1 \mathrm{~b}$, and Table 1). These features cluster in a zone of the widest valley cross-sections (between sections II and $\mathrm{V}$ in Figures $1 \mathrm{~b}$ and 2), and generally gentle slopes (at least on one side; Figures 2a and 2b). In asymmetric sections of the Colca Valley, the studied landslides concentrate on the northern, i.e. gentler side (landslides A, B, C in Figure 2a).

\subsubsection{Landslide beneath Pinchollo (A)}

This relatively small landslide, i.e. covering the area of less than $1 \mathrm{~km}^{2}$, (Table 1 ) is located to the north of the village of Pinchollo, on the north flank of the Colca River, ca. $5 \mathrm{~km}$ west of the village of Madrigal (Figures 1b, 2, and 3a; Table 1). The landslide is characterized by a semicircular outline (Figure 4a). Landslide foot reaches a nameless right-bank tributary of the Colca River (Figure 4a). Major and secondary scarps, NE- to NNE-striking extensional cracks, with lengths, usually not exceeding few meters, and rotated blocks of colluvial deposits are very common features, especially in the middle and lower part of the landslide (Figure 4a, 4b). The surface is extremely uneven, with minor undulations, frequent secondary scarps (generally not exceeding $1 \mathrm{~m}$ height; Figure 4b), fissures, and small ponds. In the lowermost part, the material is oversaturated with water even during the dry season, making the terrain very slippery and swampy. Locally, at the foot of the main escarpment, and close to the river, subsequent small-scale secondary mass movements were observed.

The landslide beneath Pinchollo was formed in the Pleistocene lacustrine sediments and poorly consolidated Pleistocene-Holocene colluvial and alluvial deposits. In the lowermost part, it reaches the deposits of a large Pleistocene rock-avalanche (volcanic debris and lava) from the Hualca Hualca volcano (Figure 3a). The upper and northern parts of the landslide are covered with sparse vegetation, i.e. eucalyptus trees that do not show tilting or other evidence of mass displacements, whereas the middle and especially lowermost parts are almost completely bare, with the only intermittent occurrence of grass. This finding suggests the potential recent activity of the lower part of the landslide in relation to the more stable upper sections (observed eucalyptus trees suggest at least 30-40 years of relative stability). The Google Earth satellite images corroborate current mass movement processes in the $\mathrm{W}$ part of this landslide within the last 10 years, mainly due to being undercut by the small right-bank tributary of the Colca River (Figure 4a), as well as oversaturation with water. The landslide shows a complex failure mechanism. The central part is dominated by the rotational type of movement, with tilted blocks and material being rotated between secondary scarps (see Figure 4b), while the lower parts with small-scale 

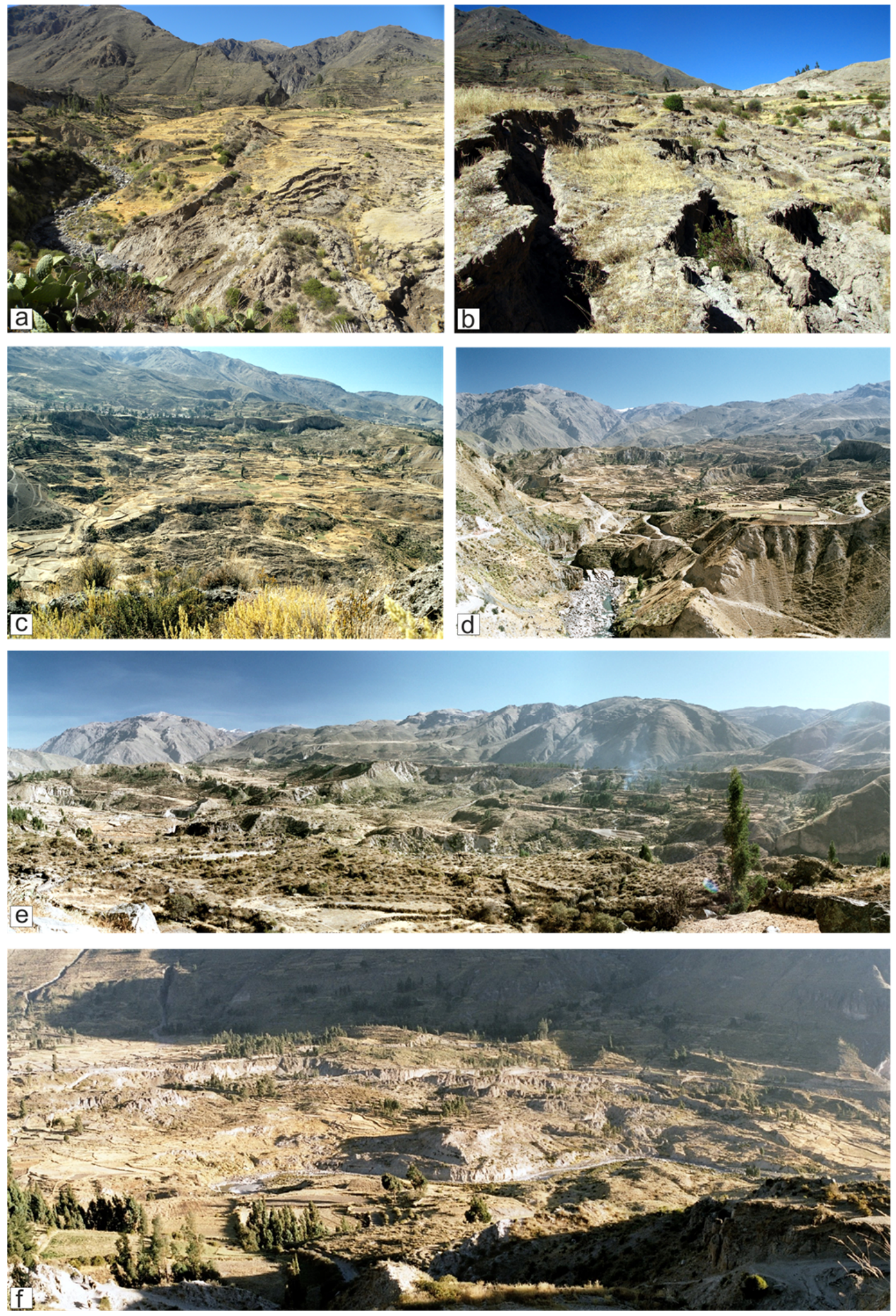

Figure 4 Studied landslides; (a) beneath Pinchollo (A in Figures 1b, 2b and 3a and Table 1); (b) minor secondary scarps within landslide A with slight rotational deformation; (c) landslide in Madrigal (B in Figures $1 \mathrm{~b}$ and 2 and Table 1); (d) between Madrigal and Lari (C in Figures 1b, 2b and 3a and Table 1); (e) landslide in Lari, photograph thane the opposite side of the valley (D in Figures 1b, 2b and $3 a$ and Table 1); (f) landslide in Maca (E in Figures 1b, 2b and $3 \mathrm{a}$ and Table 1$)$. 
horst-and-graben like structures, fissures, oversaturation with water, and very gentle slope show characteristics of translational sliding, grading to earthflow at landslide toe, with the remobilized material constantly undercut and removed by the Colca tributary (Hungr et al. 2014).

\subsubsection{Landslide in Madrigal (B)}

This large landslide $\left(\sim 1.5 \mathrm{~km}^{2}\right.$; Table 1$)$ is located southwest of the village of Madrigal (Figures 1b, 2, and 3a). Its extensive semicircular head scarp, with a radius of more than $1 \mathrm{~km}$, is clearly marked in the morphology (Figure 4c). The upper part of the landslide is bounded by almost vertical landslide escarpments reaching forty meters in height. These scarps, along with the accompanying NW-striking extensional fissures (usually of a few meters length), reach nearly as far as the outermost buildings of the village (Figure 4c). The sidewalls of the main scarp are characterized by a much gentler inclination, forming characteristic stair structures with heights usually not exceeding several meters.

The landslide in Madrigal was developed mainly in the poorly consolidated lacustrine sediments, represented by tuffites and colluvial deposits. Secondary NW-striking scarps and fissures, together with small ponds (up to $100 \mathrm{~m}$ in diameter) are widespread within the foot of the landslide (Figures $4 \mathrm{c}$ and 5 ). The upper part shows some stabilization with growing trees and agricultural terraces (Figure 4c). However, small, shallow recent debris flow and slides can be also observed here (Figure 5). The lower part of the landslide shows evidence of activity, especially below secondary, several meters high, semicircular scarp (Figures 4c, 5). The most important include an uneven landslide surface, with minor undulations, secondary NW-striking scarps of up to 1-2 $\mathrm{m}$ height, and fissures, as well as small sag ponds (Figure 5). The material here is oversaturated with water. The toe of the landslide reaches the Colca River, which successively washes out its material (Figures 4c, 5). Even though the visual interpretation of Google Earth satellite images from different acquisition time does not show any significant changes within the last 10 years, slow-moving processes are possible in this section of the landslide.

The landslide in Madrigal was developed on a steep slope of the valley in poorly consolidated, water-saturated clay sediments, permanently undercut by the Colca River (Figure 5). Slide processes acted parallel (i.e. in the direction of the Colca River) to the stratification surfaces of the underlying Mesozoic sedimentary complexes, which are gently inclined towards the SSW, i.e., the same orientation as that of the largest gradient of the valley slopes (Figure 5). Due to the relatively low difference of elevation between the scarp and
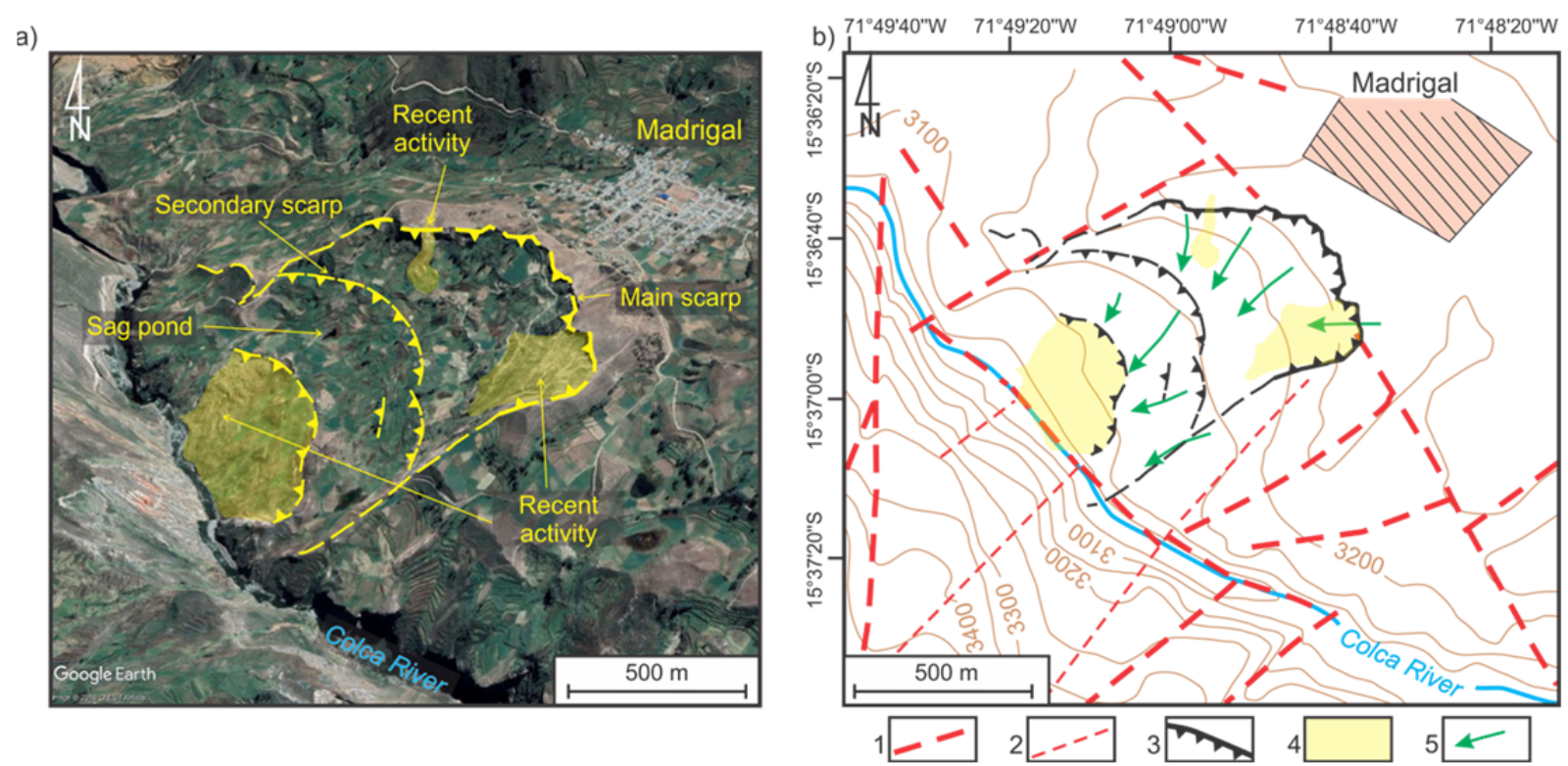

Figure 5 Landslide in Madrigal (B) and its relation to fault network; (a) satellite image from Google Earth; (b) topographic map; 1 - major faults, 2 - local, minor faults, 3 - main landslide scarps, 4 - mudflow, 5 - landslide displacement direction. 
the landslide toe (in relation to its length), sliding parallel to the bedrock stratification surfaces, water-saturated clay material, the horst-andgraben like structures, near-vertical scarps, and common extensional features and sag ponds, we believe that the landslide mechanism is complex and associated with translational sliding (Hungr et al. 2014).

\subsubsection{Landslide between Madrigal and Lari (C)}

With an area of $>5 \mathrm{~km}^{2}$ (Table 1), this feature, located between the villages of Madrigal and Lari, is the largest landslide in the studied area (Figures $1 \mathrm{~b}, 2$, and 3a). A large head scarp with an irregular outline inclines to the south (Figure 4d). The landslide was developed at elevations ranging from $3098 \pm 7 \mathrm{~m}$ a.s.l. (the toe of the landslide, undercut by the Colca River) to $3420 \pm 15 \mathrm{~m}$ a.s.l. (the upper edge of the main landslide scarp just below the road linking Madrigal and Lari). Thus, the landslide's height is $>300 \mathrm{~m}$ (Table 1 ).

This landslide consists mainly of poorly consolidated deposits represented by lacustrine series of tuffites and overlying colluvial sediments, overlapping locally with alluvial deposits from the Colca River. The landslide seems to be of the complex mechanism type (Hungr et al. 2014). After an initial slide combined with some rotation, further movement of over-saturated material occurred, probably, in the form of ground lateral flow. The lower part of the landslide presents characteristic hummocky like landscape with horst-and-graben like structures and fissures, indicating relatively higher activity than the other sections of this feature. The sliding towards the SSW occurred in the same direction as the steepest gradient of the valley slopes and stratification surfaces of the Mesozoic sedimentary strata (Figure 4d).

\subsubsection{Landslide in Lari (D)}

This landslide is located just to the south of the village of Lari (Figures 1b, 2, and 3a). A wide, c. 1.5 $\mathrm{km}$ long, roughly semicircular WNW-striking $60 \mathrm{~m}$ high main scarp (parallel to the Colca River in this section) is clearly visible in the morphology of the area, inclining to the south toward the Colca River. This landslide was developed mainly within lacustrine sediments and to a much lesser extent in colluvial and alluvial deposits. The colluvium material was moved downslope following the steepest gradient of the valley slope, i.e., towards the south.

A large part of this landslide was reshaped by the agriculture terraces, which commonly occur especially in the eastern part of the landslide and close to its toe (Figure 4e). This might suggest that these parts have been inactive for the last at least 20-30 years (as suggested by local testimonies), or the rate of displacement was relatively lower. A recent study shows also the inactivity of this landslide within the last 28 years (Bontemps et al. 2018), confirming our field observations. The western section, on the other hand, shows a similar hummocky landscape with secondary scarps and counter-scarps creating depressions filled with temporal ponds, as in the previously mentioned structures A, B, and C, but to a much lower extent. These observations suggest a relatively lower activity than those inferred for the other landslides.

\subsubsection{Landslide in Maca (E)}

The landslide in Maca is characterized by a semicircular head scarp (Figure 4f), extending along the Colca River on the left (southern) slope of the valley for a distance of $<2 \mathrm{~km}$. The village of Maca is located in the marginal, southeastern, part of the landslide, being significantly threatened by its activity (Figures 1b, 2, and 3a). The landslide developed in poorly consolidated rock-avalanche deposits and alluvial materials and lacustrine sediments. The slides occurred towards the north following the steepest gradient of the valley slope.

The surface of the foot of the landslide is very uneven. We observed numerous WSW- to WNWstriking secondary landslide scarps, with amplitudes of up to several meters, horst-andgraben like structures, and extensional fissures with openings of up to $0.5 \mathrm{~m}$ (Figure 6). Temporal ponds with a diameter of up to $100 \mathrm{~m}$, filling depressions produced by the above-mentioned features are also observed in this landslide. Landslide scarps often intersect, creating multidirectional complex systems of horst-andgraben like structures (Figure 6). These features together with sag ponds in the lower part, and no agricultural terraces (i.e. preserved only beyond the area of the landslide) suggest relative activity of the landslide. Whereas for previously described mass movement features, evidence of relative activity 

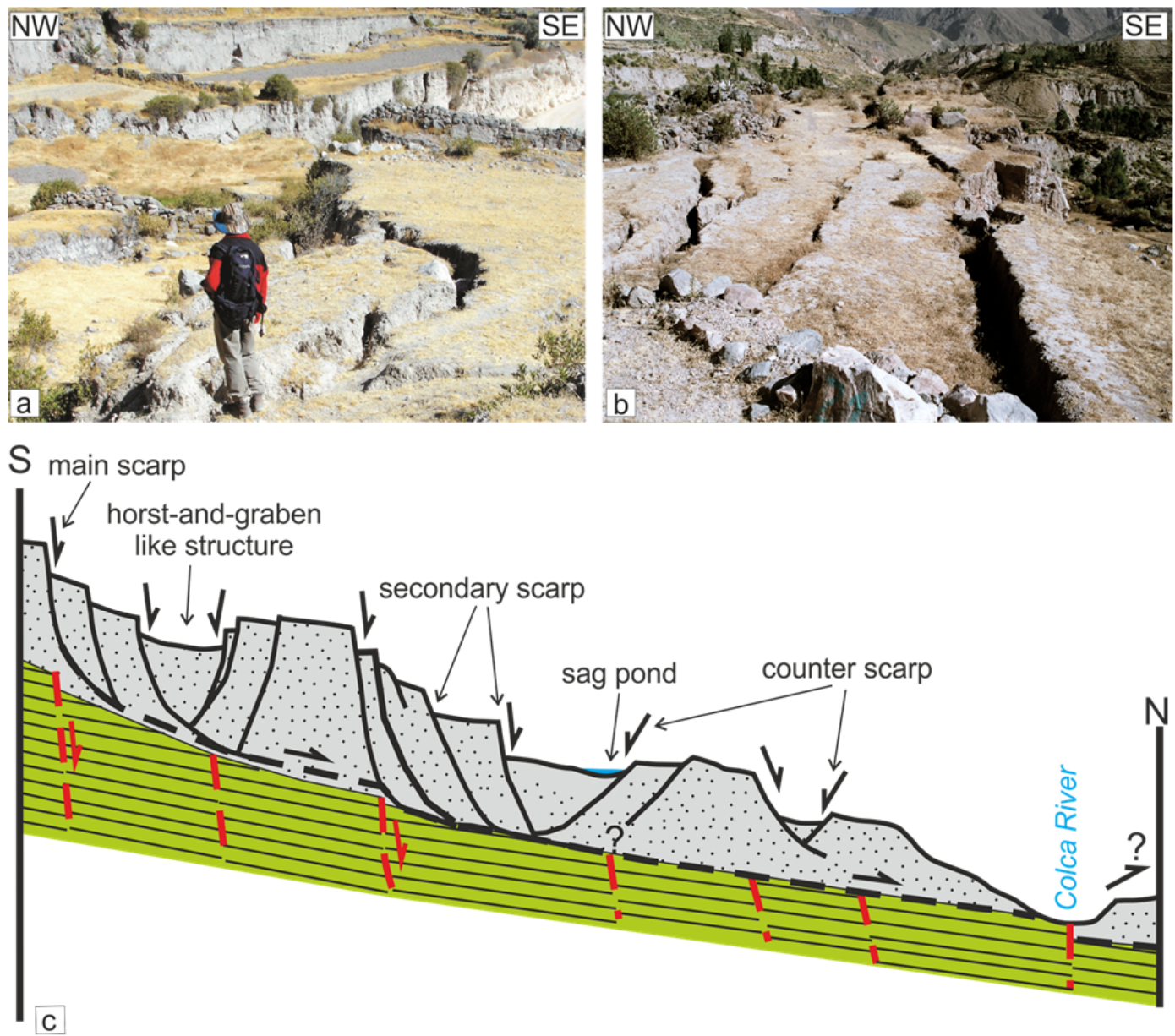

Figure 6 (a) and (b) Horst-and-graben like structures in the Pleistocene-Holocene deposits in the Maca landslide (E); (c) Idealized sketch of the development of horst-and-graben structure like features in colluvial deposits within the Maca landslide (E); schematic model, not to scale: gray - Pleistocene-Holocene fluvio-lacustrine and avalanche deposits, green - Mesozoic sedimentary strata, dashed black line - potential location of the failure plane; red dashed line - potential fault in a bedrock.

cluster mainly in the lowermost sections, in the Maca landslide the entire central part appears to show signs of ongoing displacements, which agrees with the results of other studies (Lacroix et al. 2014, 2015; Zerathe et al. 2016; Palmer 2017; Bontemps et al. 2018, 2020).

\subsection{Fault network}

\subsubsection{Mesozoic sedimentary strata}

Based on field measurements and analysis of remote sensing data, we identified a complex fault network in the Mesozoic sedimentary series (Figure 3a and 3b). The bedding of the Mesozoic formations dips gently towards the south and less commonly towards the north. It is gently folded, forming $\mathrm{W}$-trending wide, open slightly asymmetric folds produced under N-S compression.
Locally observed normal (extensional) W-striking faults appear to be related to the top of anticlines (e.g. sites 3 and 6 in Figure 3b). Younger faults, mainly strike-slip and normal dip-slip, are especially common in this area (Figure 3). Among them, frequently occur faults that are transverse in relation to the main folds (e.g. sites 2, 3, and 4 in Figure 3 b). W-striking subvertical faults show at least two phases of strike-slip displacements, with sinistral displacement as the younger phase. In some areas, these present only dextral displacements. Transverse (i.e. N- to NE-striking) and diagonal (NW-striking) structures are represented mainly by steep and very steep to subvertical normal-slip faults. Near Maca the reported fault network cuts and displaces not only Jurassic and Cretaceous sedimentary formations but also overlying Miocene tuffs, suggesting that 
observed strike-slip and normal-slip faults were active within the last $20 \mathrm{Ma}$, i.e. potentially reactivated during the Miocene-Pleistocene Quechua phase (Pfiffner and Gonzalez 2013).

\subsubsection{Pleistocene-Holocene deposits}

The faults observed in the Mesozoic formations are commonly repeated in the Pleistocene-Holocene colluvial and lacustrine deposits (Figure 3). We found structures of the same orientation of fault surfaces, as well as the same orientation of striations and the same kinematics in both the Mesozoic strata and the Pleistocene-Holocene deposits. This finding suggests that not only were these faults active within the last $20 \mathrm{Ma}$, but their activity continued within the last 2.5 Ma. Some of these agree with the spatial orientation of the Quaternary faults shown by Benavente et al. (2017), e.g. the NW-striking strike-slip faults and WNW- to NW-striking normal structures.

Among recorded structures, WNW- to NWstriking normal and oblique-slip faults produced under a sinistral transtensional regime predominate (especially in the eastern part of the studied section of the Colca Valley; Figure 3a). Left-lateral displacements along those structures were accompanied by the development of extensional strike-slip duplexes and sinistral, lowangle NW-striking Riedel shears. Latitudinal to WSW-striking right-lateral strike-slip and normal faults and NW-striking sinistral faults represent a younger generation. $\mathrm{N}$-striking steep normal faults cut and displace all the above-mentioned fault sets, suggesting that these are the youngest structures. Left-lateral displacements along the NW-striking faults agree with the sinistral Peruvian Sliver motion resulting from strain partitioning in the oblique plate convergence recorded in the subduction zone of the Nazca plate beneath the South American plate in the Peruvian segment (Villegas-Lanza et al. 2016).

\section{Discussion}

Large slow-moving landslides in the Colca Valley have been studied intensively in the last years (e.g. Guillande and Salas 1995; Bulmer et al. 1999; Antayhua et al. 2002; Gomez et al. 2002; Ocola and Gómez 2005; Żaba and Małolepszy
2008; Zavala et al. 2013; Lacroix et al. 2014, 2015; Zerathe et al. 2016; Palmer 2017; Bontemps et al. 2018, 2020). Data presented in these studies show undoubtedly that rainfall, earthquakes, and changes in the Colca river course leading to erosion of the landslide toe are the principal factors triggering landslides and controlling their velocity (Lacroix et al. 2014, 2015; Zerathe et al. 2016; Bontemps et al. 2018, 2020). Thus, in this study, we discuss the relationship between the tectonic structures, both active and inactive, and the distribution, size, and direction of the main landslide features.

\subsection{Passive tectonic control on the landslide development}

Apart from the previously mentioned factors, the distribution and sizes of the studied landslides appear to be controlled by inherited faults of different ranks (Figure 3a and 3b). Head scarps of the studied landslides generally follow the WNWto NW-direction, i.e. the prevailing trend of the Colca Valley in this section (Figures 1b, 2b, and 3a). Structural data collected in both, the Mesozoic sedimentary strata and the Pleistocene-Holocene deposits, reveals normal and strike-slip left-lateral faults of the same orientation (Figure 3a). These faults produce also remotely detected lineaments in the Colca Valley area and the Valley of Volcanoes region (Antayhua et al. 2002; Żaba et al. 2012), and first-order fault structures, causing the outcrop of the Precambrian rocks below the Colca Canyon (Mégard et al. 1971). Some of them even show evidence of recent seismic activity, like the NWstriking Ichupampa Fault (Tavera et al. 2016). A similar orientation and sense of relative displacements are presented by the left-lateral transpressional Incapuquio fault system structuring the front of the Western Cordillera in southern Peru (Jacay et al. 2002; Benavente et al. 2017). These structures, commonly replicated from the Mesozoic bedrock into the Quaternary deposits, limit the studied landslides. This situation is especially well seen in landslides A, B, and E (Figure 3a). Their abundance in the field outcrops generates zones of weakness that favor the development of failure surfaces leading to mass wasting processes. Moreover, these could also lead to over-steepening of the slopes resulting in a 
decrease in slope stability (Carlini et al. 2016).

Whereas the head scarps appear to be limited by the WNW- to NW-striking faults, the lateral extent of some of the reported features seems to be connected with the NNE-striking normal faults, common in both, the Mesozoic strata and the Pleistocene-Holocene deposits (Figure 3a). The influence of these structures is particularly clear in landslide A (Figures 1b, 2b, and 3a). This feature is bounded from the east with a clear scarp that corresponds with these normal faults. Of similar orientation are also secondary scarps within the landslide body (see Figures 2b, $4 a$ and $4 b$ ). Moreover, such structures predominate also in a nearby outcrop of the Quaternary lacustrine deposits (Figure 3a). A similar situation is observed in landslide $\mathrm{B}$, i.e. the lateral extent of this feature coincides with the NNE-striking faults and corresponding lineaments (Figure 5), whereas the head scarp follows the trace of the NW-striking fault (Figure 5) that links with the active fault presented on a neotectonic map (Benavente et al. 2017). The location and orientation of the inner rock spur in landslide $\mathrm{C}$ (in Lari; see Figures $1 \mathrm{~b}, 2 \mathrm{~b}$, and 3a) dividing the lower, active part of this landslide into two sections, mimics both, the NNEstriking faults observed in the field, and similarly oriented lineaments (Figure 3a). The correlation between these structures does not seem to be coincidental. These lineaments are also used by the Collpa stream that crosses and incises the whole body of the landslide from north to south (Figure 3a).

The best-known Maca landslide (E) (e.g. Żaba and Małolepszy 2008; Zavala et al. 2013; Lacroix et al. 2014, 2015; Zerathe et al. 2016; Palmer 2017; Bontemps et al. 2018, 2020) also show correlation with recorded faults network. Its southern limit follows the WNW-striking lineaments and faults observed in the vicinity of this slow-moving landslide in both, the Mesozoic strata and the Quaternary deposits (Figure 3a). The orientation of the clearly marked in the morphology inner structures of the landslide, i.e. horst-and-graben like structures and fissures, etc., is associated with landslide mechanism, i.e. translational displacement, rather than tectonic structures (Figure 6).

The relationship between active faults presented on a neotectonic map (Benavente et al.
2017) and the studied landslides is not straightforward. Some of the landslide features follow the direction of these active structures, e.g. the NW- to WNW-striking strike-slip fault appears to be on the northern limits of landslide B, whereas $\mathrm{W}$-striking normal fault to the south of Maca village corresponds with the head scarp of landslide E (Figures $3 \mathrm{a}$ and 7 ). However, their actual control on the limits or location of mass movement processes is questionable, as landslides do not intersect with them. Nevertheless, we cannot neglect the importance of the potential seismogenic activity of these structures on the development of studied landslides.

The detachment surfaces of studied landslides are the most probably related to units contact (i.e. bedrock and lacustrine/colluvial deposits) and/or internal differences in the Quaternary deposits, as we do not see bedrock material remobilized during mass movement processes. In most of the cases (landslides C, D and, E) the sliding occurred in the same direction as the steepest gradient of the valley slopes and stratification surfaces of the Mesozoic sedimentary strata (we do not have such data for landslides A and B; Figure 3a). Thus, it appears that the orientation of bedding planes might play a role in landslide formation, but there is no bedrock involved in the colluvium material itself. Either the displacements took place along the contact between bedrock and the Quaternary deposits, or it is simply a coincidence and the detachment is located within the Neogene sediments (Figure 6c). If the sliding indeed took place on contact between the bedrock and the younger sediments, then the studied landslides are not only limited by brittle tectonic structures (i.e. faults in the Mesozoic and the Neogene deposits), but their location is also predisposed by the continuous deformation structures, i.e. folds and bedding inclination in the bedrock. For example, Zerathe et al. (2016) for the landslide in Maca traced the detachment surface within the fluvio-lacustrine deposits. However, apart from these observations, we do not have any other evidence on the nature of the detachment surface, and thus further studies are needed to resolve this problem.

\subsection{Seismic impact on landslide development}

The motion of slow-moving landslides in the 
Colca Valley is strongly controlled by the local seismic activity (see also Lacroix et al. 2014, 2015). Collected eyewitness accounts corroborate that the landslide in Maca (E), was strongly affected by a shallow earthquake of magnitude 5.4 on July 23, 1991, with the epicenter located $\sim 5 \mathrm{~km}$ south of Maca (Figure 7). The event destroyed a large part of the village, together with the church, and killed 14 inhabitants. According to Bontemps et al. (2018), the landslide in Maca experienced $16 \mathrm{~m}$ of displacements between 1990 and 1996 that at least partially could be related to co-seismic and postseismic deformation. Local testimonies collected by us suggest an acceleration of the lower central part of this landslide after the seismic event. Oral testimonies collected by Zerathe et al. (2016) indicate reactivation of the landslide between 1980 and 1985, which does not contradict later acceleration after the seismic event in 1991. Lacroix et al. (2014, 2015; see also Palmer 2017) using GPS time series and Pléiades images observed also the acceleration of movement velocity in the Maca landslide (E) after seismic events in 2013 and 2016. Also, other earthquakes from the time period between 1991 and 2013 (Figure 7) potentially could show some impact on the landslide kinematics, but up to date, we do not have enough data to corroborate their influence (see also Bontemps et al. 2018). Lacroix et al. (2014, 2015) using GPS time series and Pléiades images observed also the acceleration of movement velocity in the Maca landslide (E) after seismic events in 2013 and 2016.

Even though the constant slow-movement of landslides in the Colca Valley is mainly controlled by climate (i.e. dry and rainy season), and only a minimum amount of rainfall is required to trigger them (Zerathe et al. 2016; Bontemps et al. 2018), the seismic control can be also significant (Lacroix et al. 2015; Bontemps et al. 2018, 2020). Also, the location of the study area in a seismically highly

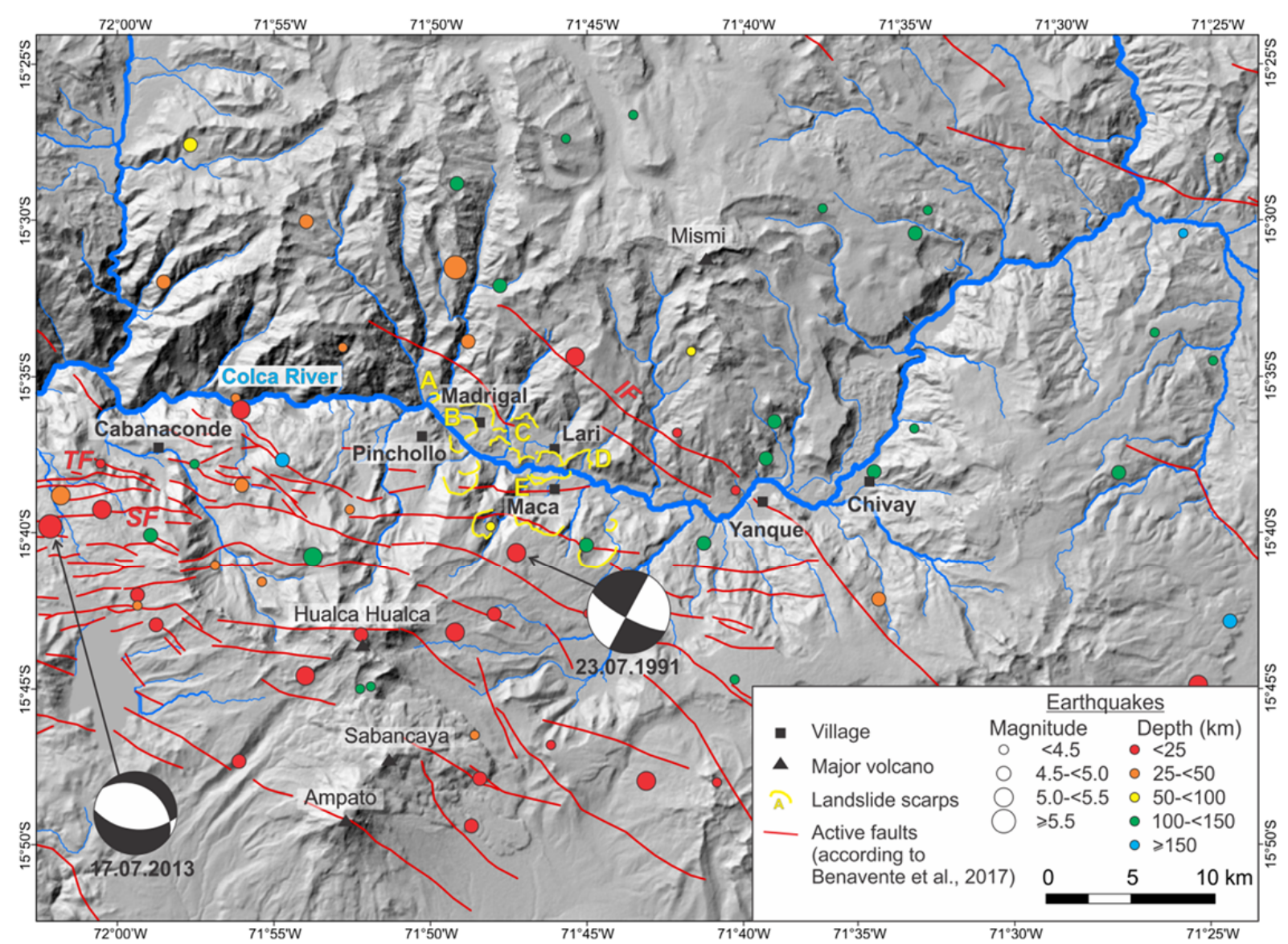

Figure 7 Major earthquakes (magnitude $M>4.0$ ) in the area of the Colca Valley for the time period 1976-2017 (USGS catalog) (https://earthquake.usgs.gov/earthquakes/search) and their relation with studied landslides. The focal mechanism presented for two selected earthquakes: 17.07.2013 (the strongest earthquake in the studied time period; magnitude $\mathrm{M}=6.0$ ) (according to Tavera et al. 2013) and 23.07.1991 Maca event $(\mathrm{M}=5.4)$ (according to Antayhua et al. 2002); TF - Trigal Fault, SF - Solarpampa Fault, IF - Ichupampa fault, A-E - studied landslides. 
active zone promotes this triggering factor. The USGS earthquake database (https://earthquake. usgs.gov/earthquakes/search) for this area includes more than 50 mainly shallow events $(\sim 60 \%$ of depth $<50 \mathrm{~km}$ ) of magnitudes greater than 4.0 , i.e., the lowest earthquake magnitude known to produce landslides (Keefer 1984), for the time period 1976-2017 (Figure 7). These events are mainly related to active regional shallow crustal faults that produce earthquakes with magnitudes usually below 6.5 (e.g. Antayhua et al. 2002), such as the normal W-striking Trigal and Solarpampa faults and the NW-striking Ichupampa fault (Sébrier et al. 1985; Benavente et al. 2017), which are, however, sufficient to trigger landslides on unstable slopes, such as those in the Colca Valley (Keefer 1984; Malamud et al. 2004; Tanyaş et al. 2017). Moreover, the area is located just $\sim 270 \mathrm{~km}$ east of the trench where the Nazca Plate is subducted beneath the South American Plate. This process is capable of producing large megathrust events of $\mathrm{Mw} \geq 8$ (Chlieh et al. 2011). These events not only can trigger numerous landslide features, as proven in many areas worldwide (e.g. Malamud et al. 2004; Wang et al. 2007; Evans et al. 2009; Gorum et al. 2011; Kargel et al. 2015; Tanyaş et al. 2017) but can also reactivate the above-mentioned shallow crustal faults (e.g. Farías et al. 2011; Shirzaei et al. 2012; Toda and Tsutsumi 2013), which may lead to other landslide features. Previous studies in the area of the Colca River pointed out that seismic shocks can cause significant mass movements, especially on steep valley slopes covered with the PleistoceneHolocene lacustrine and colluvium deposits (e.g. Bulmer et al. 1999; Ocola and Gómez 2005; Żaba and Małolepszy 2008; Zerathe et al. 2016).

Seismicity in the Colca River area may be also related to volcanic activity. Not only recent volcanic but also seismic activity of the Sabancaya and Mismi volcanoes has been monitored by the Volcanic Observatory in Arequipa (http://ovi.ingemmet.gob.pe). Its report for 200910 shows 150 seismic events in the Sabancaya volcano region of magnitudes less than 3 (Ramos and Antayhua 2011). The activity of the Hualca Hualca volcano located a few kilometers southwest of the study area triggers also numerous small seismic events (Antayhua et al. 2002). However, even though this microseismicity $(\mathrm{Mw} \leq 3)$ is not strong enough to trigger landslides (Keefer 1984), the cumulative effect of numerous seismic events can significantly undermine the stability of the slope, thus acting as a preparatory factor. As proven (Wolter et al. 2016), multiple earthquakes, even small ones, can have long-term effects that undermine slope stability through seismicallyinduced damage. Recent studies show a similar relationship between high frequency of small magnitude earthquakes and landslide stability for the landslide in Maca that can be extrapolated to most of the landslides in the Colca Valley (Bontemps et al. 2020). These observations suggest a strong impact of cumulated small earthquakes $(\mathrm{M}<4)$ combined with a high water content that prevents the landslide from recovering its rigidity, maintaining the unstable mass in a critical regime and enhancing displacements.

Large landslides analyzed in this study correspond with a zone of very high geohazard risk (9 on a scale of 0-10) (Ocola and Gómez 2005). Studied landslides covering areas of $>10 \mathrm{~km}^{2}$ make up more than $50 \%$ of the Colca valley area between Maca and Pinchollo. Thus, all villages located in the study area (Maca, Lari, Madrigal, and Pinchollo) are within the zone of high landslide risk. Scarps and extensional fissures propagate to buildings within the villages of Lari and Madrigal, whereas the village of Maca is partly located on the landslide (Figures 1b, 2, 3a, 4c, 4d, 4e). Mass movement processes also show a potential hazard to the roads 1) linking Pinchollo and Maca destroyed by a landslide during the earthquake of 1991, and 2) Madrigal and Lari with closely located landslide scarps. Landslides are also a threat to agriculture in the area, e.g. in the vicinity of Madrigal, Lari, and Maca farming terraces were destroyed during the catastrophic earthquake in 1991 and subsequent landslide. The landslide geohazard in the Colca Valley is relatively high and the need to understand mass movement processes in this region is even higher due to the recent establishment of the Colca y Volcanes de Andagua Geopark.

\section{Conclusions}

In the presented study we used geomorphological observations, structural analysis, 
remote sensing techniques using satellite images and a 30-meter resolution digital elevation model (DEM SRTM), and eyewitness accounts to determine the physical characteristics of landslides in the Colca Valley and to define the relationship between tectonic structures and landslide development. We identified five large landslides: A) beneath Pinchollo; B) in Madrigal; C) between Madrigal and Lari; D) in Lari; and E) in Maca. These features consist mainly of poorly consolidated sediments represented by a lacustrine series and overlapping colluvium and alluvial deposits. The studied landslides usually represent a complex failure mechanism, generally dominated by translational sliding (landslides A, B, D, and E), and/or rotational displacements (landslides A, C, and E), commonly associated with the formation of horst-and-graben like structures. Reported landslides are usually consequent in relation to the Mesozoic sedimentary bedrock. Our findings suggest a spatial correlation between the distribution of landslides in the Colca Valley and inherited fault network. The head scarps appear to be limited by the WNW- to NW-striking faults, whereas the lateral extent of some of the reported features seems to be connected with the NNEstriking normal faults, common in both, the Mesozoic strata and the Pleistocene-Holocene deposits. Current seismic activity, on the other hand, accelerates landslide movement. Thus, based on our results and previous studies we propose several triggering factors for slow-moving large landslides in the Colca Valley: rainfall, Colca river erosion of the landslide toe, seismic and volcanic activity, topography, soil characteristics, thick and poorly consolidated lacustrine and colluvium

\section{References}

Antayhua Y, Tavera H, Bernal I, et al. (2002) Localizacion hipocentral y caracteristicas de la fuente de los sismos de Maca (1991), Sepina (1992) y Cabanaconde (1998), Región del Volcán Sabancaya (Arequipa). Boletín de la Sociedad Geológica del Perú 93: 63-72. (In Spanish).

Benavente CL, Delgado GF, García Fernández Baca B, et al. (2017) Neotectónica, evolución del relieve y peligro sísmico en la región Arequipa. INGEMMET, Boletín, Serie C: Geodinámica e Ingeniería Geológica 64: 370. (In Spanish).

Bontemps N, Lacroix P, Doin MP (2018) Inversion of deformation fields time-series from optical images, and application to the long term kinematics of slow-moving landslides in Peru. Remote Sensing of Environment 210: 144158. deposits, lack of vegetation, common fault scarps and fault structures, and the history of landsliding in this area. However, the key factors for the landslide concentration in the Colca Valley appear to be related to 1) the availability of the Quaternary lacustrine sediments and the Pleistocene rockavalanche deposits that are relatively easy to mobilize, 2) the topographical conditions permitting the translational or rotational displacement of liquefied masses, and 3) the frequent occurrence of zones of weakness related to the fault structures in both bedrock and the Quaternary deposits. Recently the need to understand mass movement processes in this region is even higher due to the establishment of the Colca y Volcanes de Andagua Geopark.

\section{Acknowledgments}

The authors would like to thank all the members of Polish Scientific Expeditions to Peru, especially Zbigniew Małolepszy for help in the field. We thank the editor and the two anonymous reviewers for providing comments and suggestions that helped to improve our manuscript.

Open Access This article is distributed under the terms of the Creative Commons Attribution 4.0 International License (http://creativecommons. org/licenses/by/4.o/), which permits unrestricted use, distribution, and reproduction in any medium, provided you give appropriate credit to the original author(s) and the source, provide a link to the Creative Commons license, and indicate if changes were made. https://doi.org/10.1016/j.rse.2018.02.023

Bontemps N, Lacroix P, Larose E, et al. (2020) Rain and small earthquakes maintain a slow-moving landslide in a persistent critical state. Nature Communications 11: 780 .

https://doi.org/10.1038/s41467-020-14445-3

Buckham RC, Coe JA, Chavarría MM, et al. (2001) Landslides triggered by hurricane Mitch in Guatemala-Inventory and discussion. USGS, Denver, CO.

Bulmer MH, Johnston A, Engle FC, et al. (1999) Seismically triggered slope failures in the Colca Valley, Southern Peru. EOS, Transactions American Geophysical Union H41A-07: 1127.

Cannon SH, Haller KM, Ekstrom I, et al. (2001) Landslide response to Hurricane Mitch rainfall in seven study areas in 
Nicaragua. USGS, Denver, CO.

Carlini M, Chelli A, Vescovi P, et al. (2016) Tectonic control on the development and distribution of large landslides in the Northern Apennines (Italy). Geomorphology 253: 425-437. https://doi.org/10.1016/j.geomorph.2015.10.028

Chlieh M, Perfettini H, Tavera H, et al. (2011) Interseismic coupling and seismic potential along the Central Andes subduction zone. Journal of Geophysical Research 116: B12405.

https://doi.org/10.1029/2010JBoo8166

Delgado F, Zerathe S, Audin L, et al. (2019) Giant landslide triggerings and paleoprecipitations in the Central Western Andes: the Aricota rockslide dam (South Peru). Geomorphology 106932. https://doi.org/10.1016/j.geomorph.2019.106932

Evans SG, Roberts NJ, Ischuk A, et al. (2009) Landslides triggered by the 1949 Khait earthquake, Tajikistan, and associated loss of life. Engineering Geology 109: 195-212. https://doi.org/10.1016/j.enggeo.2009.08.007

Farías M, Comte D, Roecker S, et al. (2011) Crustal extensional faulting triggered by the 2010 Chilean earthquake: The Pichilemu Seismic Sequence. Tectonics 30: TC6010. https://doi.org/10.1029/2011TCo02888

Farr TG, Kobrick M (2000) Shuttle Radar Topography Mission produces a wealth of data. Eos, Transactions, American Geophysical Union 81: 583-585.

Gaidzik K, Ramírez-Herrera MT, Bunn M, et al. (2017) Landslide manual and automated inventories, and susceptibility mapping using LIDAR in the forested mountains of Guerrero, Mexico. Geomatics, Natural Hazards and Risk: $1-26$.

https://doi.org/10.1080/19475705.2017.1292560

Gómez AJC, Macías JL, Siebe C, et al. (2004) Debris avalanche deposit of Hualca Hualca Volcano and the formation of a volcanic dam in the Colca Valley, Arequipa - Peru. In: Aguirre $G$ et al. (eds.) Neogene-Quaternary continental margin volcanism. Proceedings of the GSA Penrose Conference at Metepec, Mexico. p 26.

Gomez JC, Audemard F, Quijano J (2002) Efectos geologicos asociados al sismo del 23 de junio del 2001 en el sur del Peru, in Terremoto de la region sur del Peru del 23 Junio de 2001. Sociedad Geologica del Peru: 159-174. (In Spanish).

Gorum T, Fan X, van Westen CJ, et al. (2011) Distribution pattern of earthquake-induced landslides triggered by the 12 May 2008 Wenchuan earthquake. Geomorphology 133: 152167. https://doi.org/10.1016/j.geomorph.2010.12.030

Guillande R, Salas G (1995) Geomorphological and geological survey and pot remote sensing of the current activity of Nevado Sabancaya stratovolcano (south Peru): assessment for hazard-zone mapping. Z. Geomorph. N.F. 39: 515-535

Guzzetti F, Ardizzone F, Cardinali M, et al. (2008) Distribution of landslides in the upper Tiber River basin, Central Italy. Geomorphology 96: 105-122. https://doi.org/10.1016/j.geomorph.2007.07.015

Harp EL, Hagaman KW, Held MD, et al. (2002) Digital inventory of landslides and related deposits in Honduras triggered by Hurricane Mitch. USGS, Denver, CO.

Hsü JT (1992) Quaternary uplift of the Peruvian coast to the subduction of the Nazca Ridge: 15.5 to 15.6 degrees south latitude. Quaternary International 15-16: 87-97.

Hungr O, Leroueil S, Picarelli L (2014) The Varnes classification of landslide types - an update. Landslides, 11, 167-194.

Jacay J, Sempéré T, Husson L, et al. (2002) Structural Characteristics of the Incapuquio Fault System, Southern Peru. In: 5th ISAG, Toulouse, France, Extended Abstracts. pp 319-321.

Kargel JS, Leonard GJ, Shugar DH, et al. (2015) Geomorphic and geologic controls of geohazards induced by Nepal's 2015 Gorkha earthquake. Science 351. https://doi.org/10.1126/science.aac8353

Keefer DK (1984) Landslides caused by earthquakes. Geological Society of America Bulletin 95: 406-421.
Kukulak J, Paulo A, Kalicki T (2016) Lithology of lacustrine deposits in the Colca Valley. Journal of South American Earth Sciences 69: 152-170.

https://doi.org/10.1016/j.jsames.2016.03.008

Lacroix P, Berthier E, Taipe E (2015) Earthquake-driven acceleration of slow-moving landslides in the Colca valley, Peru, detected from Pléiades images. Remote Sensing of Environment 165: 148-158.

https://doi.org/10.1016/j.rse.2015.05.010

Lacroix P, Dehecq A, Taipe E (2019) Irrigation-triggered landslides in a Peruvian desert caused by modern intensive farming. Nature Geoscience.

https://doi.org/10.1038/s41561-019-0500-x

Lacroix P, Perfettini H, Taipe E, et al. (2014) Coseismic and postseismic motion of a landslide: observations, modeling, and analogy with tectonic faults. Geophysical Research Letters 41: 6676-6680.

https://doi.org/10.1002/2014GLo61170

Lacroix P, Zavala B, Berthier E, et al. (2013) Supervised method of landslide inventory using panchromatic SPOT 5 images and application to the earthquake-triggered landslides of Pisco (Peru, 2007, Mw8.o). Remote Sensing 5: 2590-2616. http://dx.doi.org/10.3390/rs5062590

Larsen MC, Torres-Sanchez AJ (1992) Landslides triggered by hurricane Hugo in eastern Puerto Rico, September 1989. Caribbean Journal of Science 28: 113-125.

Malamud BD, Turcotte DL, Guzzetti F, et al. (2004) Landslide inventories and their statistical properties. Earth Surface Processes and Landforms 29: 687-711.

https://doi.org/10.1002/esp.1064

Marui H, Nadim F (2009) Landslides and Multi-Hazards. Landslides - Disaster Risk Reduction, pp.435-450.

Mégard F, Dalmayrac B, Laubacher G, et al. (1971) La chaine hercynienne au Pérou et en Bolivie. Premiérs résultats. Cahiers - ORSTOM, série Géologie 3: 5-44.

Moro M, Chini M, Saroli M, et al. (2011) Analysis of large, seismically induced, gravitational deformations imaged by high-resolution COSMO-SkyMed synthetic aperture radar. Geology 39: 527-530. https://doi.org/10.1130/G31748.1

Newmark NM (1965) Effects of earthquakes on dams and embankments. Geotechnique 15: 139-159.

Ocola L, Gómez AJC (2005) Peligro geologico potencial del Valle del Colca sector medio: metodologia y aplicacion. Instituto Geofisico del Peru, Lima (In Spanish).

Palmer J (2017) Creeping earth could hold secret to deadly landslides. Nature 548: 384-386. https://doi.org/10.1038/548384a

Petley D (2012) Global patterns of loss of life from landslides. Geology 4010: 927-930. https://doi.org/10.1130/G33217.1

Pfiffner OA, Gonzalez L (2013) Mesozoic-Cenozoic evolution of the western margin of South America: Case study of the Peruvian Andes. Geosciences 3(2): 262-310. https://doi.org/10.3390/geosciences3020262

Ramírez-Herrera MT, Gaidzik K (2017) La Pintada landslide-A complex double-staged extreme event, Guerrero, Mexico. Cogent Geoscience 3(1): 1356012. https://doi.org/10.1080/23312041.2017.1356012

Ramos R, Antayhua Y (2011) Sismicidad en la Región del volcán Sabancaya (Arequipa), periodo 2009-2010. INGEMMET Informe Técnico, A6567. p 50. Available online at: http://ovi.ingemmet.gob.pe/portal_volcan/docus/publicacio nes/sabancaya/3/untitled73/index.html (Accessed on 10.11.2017) (In Spanish).

Resources Observation and Science (EROS) Center (2017) https://earthexplorer.usgs.gov/ (accessed on 21.06.2017).

Samia J, Temme A, Bregt A, et al. (2017) Do landslides follow landslides? Insights in path dependency from a multitemporal landslide inventory. Landslides 14: 547-558. https://doi.org/10.1007/s10346-016-0739-x

Sébrier M, Lavena A, Fornari M, et al. (1988) Tectonics and 
uplift in Central Andes (Peru, Bolivia and Northern Chile) from Eocene to present. Géodynamique 3: 85-106.

Sébrier M, Mercier J, Megard F, et al. (1985) Quaternary normal and reverse faulting and the state of stress in the central Andes of Perú. Tectonics 4: 895-928.

Shirzaei M, Bürgmann R, Oncken O, et al. (2012) Response of forearc crustal faults to the megathrust earthquake cycle: InSAR evidence from Mejillones Peninsula, Northern Chile. Earth and Planetary Science Letters 333: 157-164. https://doi.org/10.1016/j.epsl.2012.04.001

Tanyas H, Westen CJ, Allstadt KE, et al. (2017) Presentation and Analysis of a Worldwide Database of Earthquake Induced Landslide Inventories. Journal of Geophysical Research, Earth Surface 122: 1991-2015. https://doi.org/10.1002/2017JF004236

Tavera H, Buforn E, Bernal I. et al. (2002) The Arequipa (Peru) earthquake of June 23, 2001. Journal of Seismology 6: 279283. https://doi.org/10.1023/A:1015698621075

Tavera H, Guzman J, Velarde L, et al. (2016) Sismo de Ichupampa del 14 de Agosto del 2016 (5.3 ML), Aspectos Sismológicos. Centro Nacional de Monitoreo Sísmico Acelerométrico, Instituto Geofísico del Perú, Lima, 16 p (In Spanish).

Tavera H, Martinez J, Fernandez E, et al. (2013) Sismo de Huambo-Cabanaconde (Arequipa) del 17 de Julio, 2013 (5.7 ML), Aspectos Sismológicos. Dirección de Sismología, Instituto Geofísico del Perú, Lima, p. 30 (In Spanish).

Thouret JC, Wörner G, Gunnell Y, et al. (2007) Geochronologic and stratigraphic constraints on canyon incision and Miocene uplift of the Central Andes in Peru. Earth and Planetary Science Letters 263(3-4): 151-166. https://doi.org/10.1016/j.epsl.2007.07.023

Toda S, Tsutsumi H (2013) Simultaneous Reactivation of Two, Subparallel, Inland Normal Faults during the Mw 6.6 11 April 2011 Iwaki Earthquake Triggered by the Mw 9.0 Tohokuoki, Japan, Earthquake. Bulletin of the Seismological Society of America 103: 1584-1602.

https://doi.org/10.1785/0120120281

Torres D, Muñoz L (2009) Mapa Geológico del Cuadrángulo de Chivay, 32-s-IV, 1:50000. Ingemmet, Lima, Peru (In Spanish)

USGS Earthquake Database (2019) Available online at: https://earthquake.usgs.gov/earthquakes/search (accessed on 17.11.2019).

Villegas-Lanza JC, Chlieh M, Cavalié O, et al. (2016) Active tectonics of Peru: Heterogeneous interseismic coupling along the Nazca megathrust, rigid motion of the Peruvian Sliver, and Subandean shortening accommodation. Journal of Geophysical Research, Solid Earth 121(10): 7371-7394. https://doi.org/10.1002/2016JB01308o

Volcanic Observatory in Arequipa (2017)

https://ovi.ingemmet.gob.pe (accessed on 17.11.2017).

Wang HB, Sassa K, Xu WY (2007) Analysis of a spatial distribution of landslides triggered by the 2004 Chuetsu earthquakes of Niigata Prefecture, Japan. Nature Hazards 41: 43-60. https://doi.org/10.1007/s11069-006-9009-x

Wolter A, Gischig V, Stead D, et al. (2016) Investigation of Geomorphic and Seismic Effects on the 1959 Madison Canyon, Montana, Landslide Using an Integrated Field, Engineering Geomorphology Mapping, and Numerical Modelling Approach. Rock Mechanics and Rock Engineering 49: 24792501. https://doi.org/10.1007/s00603-015-0889-5

Wu C, Qiao J (2009) Relationship between landslides and lithology in the Three Gorges Reservoir area based on GIS and information value model. Frontiers of Forestry in China 4: 165-170. https://doi.org/10.1007/s11461-009-0030-6

Zaba J, Małolepszy Z (2008) Landslide hazard related to tectonic activity in the Rio Colca Valley, Peru. Problems of the environmental resources managment. Mineral Resources Managment 24: 117-134 (In Polish).

Żaba J, Małolepszy Z, Gaidzik K, et al. (2012) Fault network in Rio Colca Valley between Maca and Pinchollo, Central Andes, Southern Peru. Annales Socieatis Geologorum Polonae 82: 279-290.

Zavala B, Mariño J, Lacroix P, et al. (2013) Evaluacion de la seguridad fisica del distrito de Maca, Estudio geologicos, geofisicos y monitoreo de movimientos en masa, Informe Tecnico No. A6628. INGEMMET-IRD-IGP Publications, Lima (In Spanish).

Zerathe S, Lacroix P, Jongmans D, et al. (2016) Morphology, structure and kinematics of a rainfall controlled slow-moving Andean landslide, Peru. Earth Surface Processes and Landforms 41: 1477-1493. https://doi.org/10.1002/esp.3913 